Teosofia: Indonesian Journal of Islamic Mysticism, Volume 7, Number 1, 2018

\title{
SYAṬAHĀT OF THE SUFIS AND THE ISSUE OF HUMAN CONSCIOUSNESS
}

\author{
Dzikrullah Zulkarnain \\ Ansor Sufi Center \\ zulkarn_ain@yahoo.co.id
}

\begin{abstract}
This research empasizes on digging the consept of Syatahat of Sufis where several tasawuf companion showed their psychological condition up on paradoct position, switces themselves on God position. Then, trought researching on Syatahat of Sufis in psychological approach, researcher found several conclusions; i.e. (a) etimologically, Syatahăàt means shaking (al-harakah); (b) terminologigally, Syạtahat of Sufis means any speeches that stranged to be heard by its audience when Sufis reached wajd or wujūd level. The factors that force the Sufis said Syạtahat were: (1) the strong emotional feelings and rumbled spiritual extasy (wajd), (2) experiences self unification (ittị̄äd), (3) Sufis are in extacy condition (sakr), (4) Sufis hear the signal of divinity within them who invites self-union, so they positioned himself as God, and (5) they loss of self-consciousness; Additionally, the researchers added the other factors, i.e. (1) the Sufis movement comes from tawäjud (salat, dhikr, meditation, contemplation, thought) on to the wajd or ecstasy level, (2) when Sufis heart is suddenly controlled by Allah Almighty (wārid al-iTahiyyah), so he was no longer able to control their consciousness, and (3) absence of prejudice that the Sufis are united with God, because when that feeling comes, then they really had split (infisāl). In other hand, Syatahă of Sufis in psychological perspective, this study focused on transpersonal psychology, researchers tried to draw the conclusion that remarks Syatahat in grammatical word used is a combination of words which are not common to say by common, because the context is only for Allah. Those unusual utterances are manifestation of Sufis psychology themselves, when saying syatahăt, Sufis do not realize whatever they have been said.
\end{abstract}

Keywords. syațahāat, extasy, psychology, Sufis

\section{Introduction}

7 he public imagination of the syatahăt $t^{1}$ of the Sufis -who are not a few among the Sufis must be executed for the sake of their syatahăt- has caused confusion for lay people who strongly hold shariah. This very confusion has resulted in some adherents of feeling.

${ }^{1}$ It is strange expression of sayings which comes up from the certain condition/ ecstasy of their spiritual 
tasawwuf revealing his condition in a form that paradoxically positions them outside the community of believers. This condition is caused by differences in the ways of monotheism between Sufis and fiqh scholars.

Ibn Ataillah divided the Sufis who reach the level of ma'rifat into two parts: sālikinn and majżūbin. ${ }^{3}$ The group of sălikin are Sufis whose search for meaning is using ground theory. This means that natural phenomena are used as evidence of the existence of Allah. Furthermore, the names of Allah are used as clues to the existence of the attributes of Allah and by the attributes of Allah are considered as proof of the existence of the essence of Allah. While the majżüin group uses the opposite theory. That is, from the beginning a Sufi must know and be sure of God first, then decline to recognize the nat ure, name and creation of God or nature. So the final goal of the group of sālikin is the first phase for majżübinn. Conversely, the first phase of sâlikin is the last phase of majżübin, because it might meet in the middle between those who use such theory (Al-Randi, $\mathrm{tt} .: 90$ )

For lay people, in the study of Sufism -which focuses more on zauq (mystical feeling), mystical experience is something universal that can be experienced by everyone in relation to their Lord, whether manifested in the form of conversations with God in state fanä' (mystical union) or syatahat. And, this possibility is a necessity that mystical experience is a universal phenomenon that can be experienced by people in relation to their God.

This research focuses on the influence of ecstasy expressions that are influential in Sufism. Expression of ecstasy (syatahăt) is an important problem in understanding sufism. Ecstasy for Sufis can be the key to God's revelation

For example, the ecstasy expression of Abu Yazid al-Bustami is the most famous

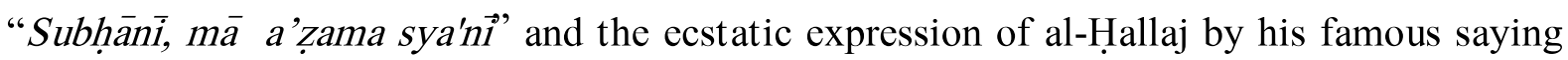
"Ana al-Haq", is truly an insightful reason for the study of Sufism.

The ecstasy expression (syatahăt) requires interpretation in some sufism vocabulary at this time. From this point of view, the expression of the Sufi ecstasy is aimed at limiting rigid legalism as it underlines the controversial origins of Sufism (Ernst, 2003: 19).

Everyone has method to spiritually go to God. For example Abū Yazid al-Bustami, he tried to go to God with the concept of al-ittihàd, i.e., one can feel himself truly feeling the feeling of being united with God, so that the only One is seen and felt. Humanity's identity has been lost and only One Being who lives is left. Then al-Hallaj with the concept of hulul, that is, God chooses a particular human body to take place in it, after the characteristics of humanity (nasutt) are omitted and what remains is only the element of divinity (lah $\bar{u} t)$.

\footnotetext{
2 Those who pass the spiritual ways to achieve/ meet God.

${ }^{3}$ Those who are spiritually attracted by God so that they in terms of their sayings and behaviors would seem not normal for lay people.
}

Teosofia: Indonesian Journal of Islamic Mysticism, Volume 7, Number 1, 2019 
When unification occurs, both in the form of hulul and in the form of ittihăd then at that time one can issue a strange statement (syatahāt), which may be considered eccentric by lay people who do not have insight into Sufism. In the view of psychology, the statements that emerge from the subconscious area of the human body give rise to the assumption that those statements are called syatahăt. Syatahăt itself invites questions of universal human view of the relationship to God and offers testimonials that have extraordinary challenges for conventional religious meanings.

This research specifically studies on the biographies and works of the Sufis; two works of Qasim Muhammad Abbas: Al-Hallaj: al-A'māl al-Kāmilah; and Abu Yazìd al-Bustamī: alMajmu'ah al-Ṣfiyah al-Kämilah; the work of Ali ibn Anjab Al-Baghdadi: Akhbar al-Hallaj min Andari al-Ușul al-Makhtutăt fi Sirati al-Hallaj; two works Abd al-Halim Mạ̣mūd: Sultān al- 'Árifin Abu Yazìd al-Bustamī, and Tàj al-Șufiyah Abu Bakr al-Syibli Hayatuhu wa Arä'uhu.

The discussion about Syatahiyät of the Sufis, was referenced and studied from the book Al-Lumma' fi al-Tasawwuf, the work of Sarraj al-Tūsì. This book contains ideas about the Syatahiyat. To find out the intellectual response to the concept of Syatahiyat of the Sufis, then some data is taken through the thoughts of several prominent Muslim thinkers who know the thoughts of Sufi figures. of the syatahăt with a hermeneutical analysis knife, the researcher will interpret grammatically to obtain the meaning of the text, and try to explore the psychological interpretation of Sufis, paying attention again the socio-historical context, so that researchers can enter life and history, where the text originates, and enter into Sufi psychology.

\section{Tauhid as the Foundation of the Syatahăt of Sufis}

The essence of the experience of diversity is how Sufis understand creed. The creed sentence, or recognition of Islam's acceptance, confirms: "There is no God but Allah". The name of God is "Allah" and occupies a central position in every position, action, and thought of every Muslim. God's presence fills Muslim consciousness at any time. In the true Muslim view, God is not merely a 'first cause' as the theologian has described it and a high ultimate. Rather, it is more than that, namely that He is the core of negativity. God as the core of normalization means that $\mathrm{He}$ is the Supreme Ruling One. His movements, thoughts, and deeds are realities that are impossible to deny and doubt. Each of these things, as long as humans understand them, is a value for him and a necessity. To arrive at the union, the author presents several important elements that will be passed by a Sufi, namely: an explanation of the human soul, the position of consciousness in the human soul and term tawäjud, wajd and wujūd.

\section{a. Human Soul}

In humans, there are qalb and rüh. Both of them can access the empirical realm or supernatural or abstract nature. According to Imam al-Ghazali, the word qalb can be 
interpreted as two kinds; first, special meat, shaped like a round, longitudinal pine located on the left chest, in which there are cavities filled with blood; and second, something subtle (latiffah), which is in the human self, which is divine (rabbaniyyah) and spirituality (rühäniyyah) who is able to feel, know, recognize and be talked to, tortured, reviled, and sought. Because of this meaning, qalb is often called the human nature (haqiqqah al-insān) (AlGhazāTi, tt: 3).

Likewise with the word rüh. Al-Ghazali interpreted it with two meanings. First, it is interpreted as something subtle (jinsun latif), which originates from the hole of the physical heart, which is spread through veins that extends all over the body. Rüh it flows to the body and has the ability to give light to life, feeling, sight, hearing, and smell, like an abundance of light that surrounds the rays of the corner of the house. Second, rūh is interpreted as something subtle (al-latîifah), knowing (al-'allimah), and who perceives (al-mudrikah), which is in human beings. And this second meaning, continued al-Ghazali, is the meaning of the essential qalb (Al-Ghazāili, tt: 3-4).

Baharuddin added that one of the characteristics displayed by the soul (al-nafs) is its function to accommodate or accommodate other dimensions of the soul. Al-nafs as a basic psychological element of man implies al-nafs as one dimension of the soul which has a basic function in the arrangement of "organization" of the human soul. That al-nafs because of its greatness is able to accommodate and accommodate other dimensions, such as al- 'aql, al-qalb, al-rüh and al-fitrah. Essentially, al-nafs also accommodates the potentials of each psychological dimension, in the form of taqwa potential (good, positive), as well as fujür(bad, negative) potential (Baharuddin, 2004: 92).

\section{b. Position of Awareness in the Human Soul}

The concept that is closely attached to syatahāt is the self-awareness of a Sufi. Is the consciousness of a Sufi completely lost when issuing the statement or is still awake or conscious. Therefore, the researcher cited an explanation of human consciousness by Zohar and Marshall.

The position of consciousness in the human psyche Zohar and Marshall raised the term spiritual intelligence (SQ) but did not give definitive limitations. But they provide descriptions and explanations which are all related to the essence of SQ. Zohar and Marshall argue:

"Spiritual Quotient the intelligence with we edrees and solve problem of meaning and value. The intelligence with which we can place our action and our live in a wider, richer, meaning-giving context. The intelligence with which we can assess that one course of action or one life path is more meaningfull than anather. $S Q$ is necessary effective funcioning of both IQ and EQ. It is our ultimate intelligence"(Zohar, 2000: 4).

Teosofia: Indonesian Journal of Islamic Mysticism, Volume 7, Number 1, 2019 
According to them spiritual intelligence is intelligence that can help humans to deal with and solve various problems related to problems of meaning and value. An intelligence that will help humans to put their actions and lives in a broader and richer context of meaning. It is intelligence that can be used to judge that a person's actions and life are more meaningful and valuable than others. More than that, according to them spiritual intelligence is the "Ultimate Intelligence" of the highest intelligence that exists and is possessed by humans as well as an important condition to effectively function intellectual intelligence (IQ) and emotional intelligence (EQ).

Furthermore, Zohar and Marshall asserted that "SQ is our deep int uitive sense of meaning and value for our guide at the edge". Spiritual intelligence is the deepest feeling of meaning and value that can lead people to success and happiness in life. They also said, Spiritual Quotient is "Our conscience" because spiritual intelligence according to them is "Soul Intelligence" which can help humans to build themselves int act intellectually, emotionally and spiritually. And an intelligence that can heal humans from spiritual illness (Spiritual Phatology) and various mental health (mental disorders). Such as adversity, humiliation, helplessness, despair, anxiety, depression and stress (Zohar, 2000: 4).

It is said that spiritual intelligence is intelligence that is outside the self that has a relationship with wisdom outside the ego or conscious mind. It is an awareness that not only recognizes existing values. But creatively discover new values. Because spiritual intelligence does not depend on the culture and values that already exist in humans, spiritual intelligence makes it possible to create new values.

In the view of Zohar and Marshall, humans are "Driven indeed by longing to find meaning and value in what we do and experience", they say humans are creatures who always try to find and seek meaningfulness of life. So that human desire to make his life full of meaning and value is a very basic and strong desire, it makes in every activity and action, humans always try to get and find meaningfulness of life. In this case Zohar and Marshall asserted by quoting the opinion of Viktor Frankle who argued that, the search for the meaning of life is an important motivation in human life. This search is what makes human beings spiritual and when the need for meaning is not fulfilled, then his life will feel shallow and empty (Zohar, 2000: 9).

The basis of spiritual intelligence, said Zohar and Marshall is the existence of a God Spot. Zohar and Marshal argue: "God spots my necessary condition for SQ, but it won't be sufficient conditions." They further said: "The score of SQ wauld expected to score is highly or God Spot activity, but it does not follow that high God Spot activity quarantees high SQ". Thus, being spiritually intelligent allows one to have high activity in God Spot. But it does not 
guarantee the high activity of God Spot (God's Point) someone will have high spiritual intelligence as well (Zohar, 2000: 82).

God Spot which is in the temporal lobe of the human brain. Discovered by Ramanchandran and Micheal Pasinger. The temporal area or lobe according to Zohar and Marshal (2000), is related to the limbic system, emotional center and brain memory. Furthermore, they said, spiritual experience in the temporal lobe that lasts only a few seconds will have a very strong influence on the culprit and can change a person's attitude and behavior. This is supported by the results of research on human brain activity from the University of California San Diego which found temporal regions as one of the locations that have an important role in the mystical and spiritual feelings of humans (Taufik Pasiak, 2003: 127).

On the other hand, al-Ghazali argues that humans have an essential identity that is constant, unchanging, namely the al-nafs (soul). What is meant by al-nafs is a stand-alone substance, not located, and is a place of intellectual knowledge (al-ma'qulat) originating from the natural al-malakut or alam al-amr (Yasir Nasution, 1988: 73).

Unlike the philosophers who want to describe the human soul in a hierarchy, the Sufis describe the soul in a position or position. For Sufis, al-nafs is a human dimension that is between rū $\mathrm{h}$ and jism. Rūh carries light (nür) and jism brings darkness (zulm). Spiritual struggle (mujāhadah) is done to lift the soul towards rụ and fight various low jism tendencies (Baharuddin, 2004: 93). So in the process of the emergence of syaṭahăt later, the human soul (read = Sufis) will be more inclined towards rūh.

\section{c. Tawājud, wajd dan wujūd}

Etymologically, al-wajd in language means a feeling of joyful heart. Sufis disagree in the use of the term wajd, which is between wujdānan and wujand as attribute of wajd.

However, Sarraj in al-Lumma' mentions several definitions with clear words and meanings, as defined as "what happens in the heart in the form of panic, difficulty or seeing the meaning of conditions in the hereafter," or "which heats the witness against attention," or "What happens to the heart and reject it, without coercion and forgery" (Al-Tūsi, 1960: 375).

Wajd place is in the heart, like the whole form of happiness, sadness, pain, etc. They interpret "wajd" from the word of God [Al-Hajj [22]: 46]:

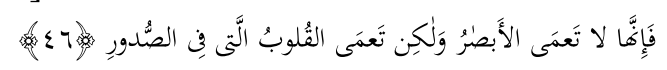

\section{"Because it really is not the eye that is blind, but the blind, is the heart inside the chest".}

From this verse it can be seen that the heart has two types: the blind heart does not see, and the heart sees and opens wide, or the heart finds, and the heart does not find, and what the heart hears and sees is what is likened to wajd. 
There are three levels of wajd: first is al-tawajud, a wajd call with mention or thought. This is the lowest level because of the results of the effort, which is for beginners in suluk, and the teachers are different at this level. Some of them stopped him because of falsehood and lack of honesty. And some of them allow it because of exposure to noble conditions, and they have chosen: the truth of tawäjud absolutely, based on the hadith: "Weep, if you do not cry, cry" Narrated by Ibn Majah in chapter Zuhud (Al-Tūsi , 1960: 307). In other words, the process of tawajjud towards wajd is a difference between the beginner's experience and the experience of the Sufis.

Wajd is a ladder that leads to divinity, which in turn is the result of dzikir and wirid. Then wirid is a condition for getting wajd. Their frequently quoted words are "those who have no wirid in their birth, so they don't have wajd in their mind" (Al-Tūsi, 1960: 307).

Because wajd is sometimes similar to self-inequality, then Sufis limit it to the boundaries of the Qur'an and Sunnah, and say: "all wajd that are not in the Book and al-Sunnah are wrong" (Al-Tūsi, $1960: 306$ ). For experts, they have changes that appear in their faces, such as shivering, shock, breathing, breathing, crying and whining, and shouting. This is for beginners who disguise their wajd and influence them because of the weakness of their hearts to bear the beams, unlike the perfect behavior of people from suluk experts, who are not worried about strong beams.

Wajd is inseparable from the Sufi preaching of Allah. Sarraj mentions the type of mahabbah to be 3 states; (a) first, mahabbah in general, born of God's kindness and mercy to them. This requirement of mahabbah is the cleansing of love, accompanied by continuous dhikr. Because whoever loves something, he will always mention it; (b) second, mahabbah arising from the heart's vision of God's greatness, majesty, knowledge, and power. This love belongs to al-ṣädiqin and al-mutahaqqiqin (people who are right and confirm the truth). In this level, it is necessary to open the magic veil or divine secrets, the disappearance of the will and all certain characteristics and desires; and (c) third, mahabbah al-sāaiqïn and al- 'ärifinn (people who are right and ma'rifat), which arise from their visions and ma'rifat they face the qadim of love of Allah without because. Likewise they love God without any tendency. In this love, someone only loves God, so that everything is with God and because of Allah, there is nothing to love but Allah. Then, the attributes of God enter into the nature of the lover, as a substitute (Al-Tū si, 1960: 88).

\section{Background of Sufis Syatạāt}

In Syarh al-Hikam 227th wisdom Ibn Abbad al-Randi explains:

$$
\text { الحقائق ترد في حال التجلي مجملة، وبعد الوعي يكون البيان؛ ( فإذا قر أناه فاتبع قر آنه * ثم إن علينا بيانه ) }
$$


The knowledge of the essence revealed by Allah to the people 'Arif when the tajalliy was global (mujmal) but after being caught, there was information. Then in QS. Al-Qiyā mat, verse 18-19: "then when We read, follow the reading, then We ourselves will explain it, meaning a detailed explanation." (Al-Randi, tt .: 39-41).

According to Ibn Abbad al-Randi in Syarh al-Hikam, the emergence of syatahăt that is when Allah tajally against the heart of the Sufi (the appearance of wārid ilāhi) where it comes suddenly so that he is no longer able to control his consciousness (Al-Randi, tt .: 41).

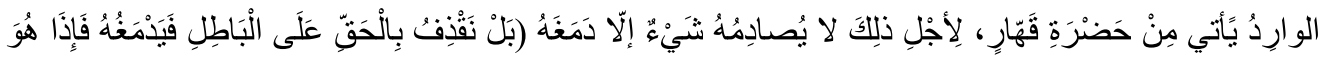

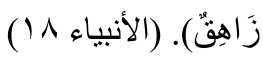

Al-Warid comes from the presence of might. Therefore, he will not be inflated with anything but he will destroy it. He is like the deceased surah al-Anbiya' verse 18] we even threw the right to the vanity, then he destroyed it. So he (ie, the vanity) disappears] (Al-Randi, $\mathrm{tt} .: 42)$.

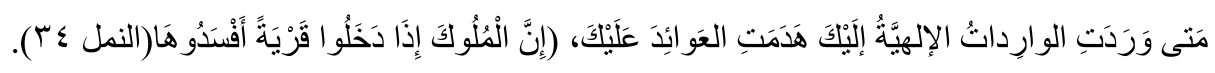

When it comes to you al-waridat al-ilahiyyah (spiritual outpouring of the divine). This alwaridat al-ilahiyyah will destroy your habits. It is nothing but a matter which corresponds to the meaning of surah an-Naml verse 34: "verily the king of kings, if they enter a qaryah (village or country) will destroy it" (Al-Randi, $\mathrm{tt} . .42$ )

From the three wisdoms above, the researcher concluded that when Allah tajalliy in the heart of a Sufi, the Sufi could not see anything except Allah. At that time Sufi was centered on God, he forgot himself and could not control the words that came out of his mouth, in other words said something accidentally. And the words that come out are global (mujmal) or not yet understood. However, when enlightenment came, the point was when Sufi regained consciousness, then it could only be understood.

The author gives an example, one day a big lion suddenly appeared in front of the reader, sometimes the reader issued words that sometimes the reader did not know what to say, because of the lion's greatness.

In addition to wărid ilähiyyah above, Al-Badawi mentioned five important factors why syatahăt can appear; (1) strong emotional feelings and spiritual ecstasy that are very turbulent (wajd); (2) experience experience of unification (ittih $\bar{a} \mathrm{~d}$ ); (3) Sufis are drunk (sakr); (4) hear the divine signal in him which invites to unification, so he changes his rotation with the spin of God; and (5) the loss of self-consciousness of a Sufi (Badawi, 1978: 10-11), all goes on with the condition of a Sufi who is not aware of his feelings, so he will say as the first person, even though he was born by birth.

Teosofia: Indonesian Journal of Islamic Mysticism, Volume 7, Number 1, 2019 
Here, wajd is the secret of Allah Almighty for those who are truly believers, believing in their beliefs as sure as they come to the hearts of the Sufis in a state of despair and feeling the presence of the Divine and the disclosure of barriers with al-Haq which removes traits of his nafs directly and suddenly. Thus, it is necessary to have a very turbulent emotional and ecstasy

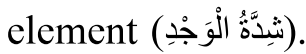

One syatahăt occurs only one time and syatahăt is a sufi which lasts only a few seconds starting when saying the phrase ecstasy until the utterance ends. And really syatahăt only appears in the condition maqāmāt wajd and maqāmät wujūd. For example, when a badminton player smashes he may issue a reaction that is different from usual; Among the reactions issued is the appearance of eccentric words from him. The whole game is maqāmāt while the smash point is ahwāl; and between aḥwāl that is really syatahăt.

If examined more deeply, syatahăt occurs in ḥăl sakr or drunkenness. Such condition has a close meaning to gaibah, namely the absence of the heart in witnessing (musyāhadah) The Most Creator (al-Khallaq) because he is present and witnesses al-Haqq without changing the servant outwardly, then he added that sakr or drunkenness is stronger and more perfect than gaibah (Al-Tūsi, 1960: 269). Thus the peak of sakr is when a Sufi experiences syatahāt in a state of omission (fana).

The idea was also agreed upon by Qusyairi, because basically Qusyairi had studied with Sarraj through his work. He said that people who are in a state of conscience are said to be more perfect and stronger than those in gaibah (Qusyairi, 1989: 153). Since the source when it occurs is not from the human nature, the other case with the sermon comes from the character of man himself.

We have signaled the hadith about the sacred until all of these conditions have overseen a syatahăt or prepared it to the point of syatahăt. Perfect in conditions of no influence. The influence here is rational thinking. When sufistic conditions are not related to their essence to consciousness, even to fatigue and taste, then there will be a retreat of influence. Because this justifies the initial position in soft conditions related to the birth of a birth of syatahăt. And to the highest level, because the conditions are the main factor for each of these conditions; that is the condition that runs in the atmosphere from the absence of influence to the furthest possible limits for Sufis. Thus, the absence of influence is a strong element in limiting normal conditions to the occurrence of syatahăt (Badawi, 1978: 15).

Al-Qusyairi compares sakr with sahw, where sakr is a state of gaibah (absence from witnessing a being followed by the presence of al-Haqq in the heart) which is very strong, while sahw represents the return of consciousness from gaibah (Qusyairi , 1989: 153). When the Sufi is aware (sahw) of wajd, then it is enough for him, but if a Sufi is drunk (sakr) then he will not be able to distinguish something and will be a very arising factor of syatahăt. Even 
so, in circumstances, Sufi will go to the level of wujüd which can deliver him to the conditions of jam'u and or tafriqah (Al-Tū si, 1960: 415-416).

Sarraj interpreted al-jam' $u$ as a global pronunciation that implies to al-Haqq outside the creation of beings and the universe. Whereas al-tafriqah as a signal to the universe and beings. Then Sarraj concluded that: "Whoever shows the state of tafriqah without jam'u, God really rejects it. And whoever shows the state of jam' $u$ without tafriqah then he (read = the Sufis) really has denied the taqdir of God. When he combines the two (jam'u and tafriqah) then he really has merged (Al-Tūsi, 1960: 416).

However, the researcher assumes that before al-jam' $u$ and or al-tafriqah a Sufi must try to take ittiṣāl, Sufis try to merge with Allah. However, when he felt ittiṣāl then he was infiṣal. Like al-Syibli's words in Luma':

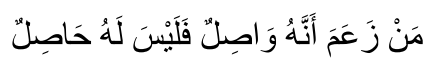

He who claims to meet (with God) is unsuccessful (Al-Tūsi, 1960: 433). And mentioned by Sarraj from several teachers that:

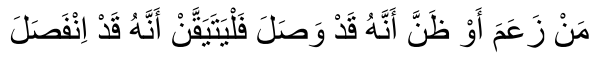

Whoever confesses or feels that he/she meets (with Allah) then rest assured that he is truly separated (Al-Tūsi, 1960: 433). The relationship between maqāmāt and aḥālin the wajd process experienced by Sufis can be seen in Diagram 1 below. And from the explanation above, syațậat can be found when aḥwāl sakr in maqāmät wajd and is found when aḥwāl jam'u and tafriqah in maqāmāt wujūd.

\section{The Sufis Syaṭahāt}

\section{a. Abu Yazid al-Busțami}

Abu Yazid's Ecstasy words are "سُبحاني سُبْحاني". It is the expressional speech that had been forgiven by Ibn Salim in Basrah. Sarraj said: "I heard one day Ibn Salim said when in his assembly: Pharaoh alone did not say what Abu Yazid said, because Pharaoh said: "I am your highest rabb". And rabb is named for creatures also like rabb in rabb al-bait (homeowner). Abu Yazid said: "Glory to me! Exalted me!" And the Holy One (subbüh and subhān) is the name of Allah that must not be used by other than Him (Sarraj, 1960: 472).

Then syatahât سُبْحَانِي مَا أَعَََْ شَأْنِي (Glory to me! How noble is my behavior!), Which behavior is more noble than to the level of divinity and is real to ittihad (unification) that is perfect with al-Haqq. This is a maximum effort and how noble is the behavior of Abu Yazid when it reaches its peak (Badawi, 1978: 37).

Once, Bayazid was followed by a large group of people who were looking for his friend. He said to God, "O Lord! I pray that you will not cover the people of yourself with your self, 
but you cover them from yourself with me!" then after leading the people in prayer, he turned to them and said, "I am I, there is no god but Me; then worship Me!" hearing this, people said, "Abu Yazid was crazy," and they left.

However, it appears that Abu Yazid -having been saved by ecstasy in the high moment-

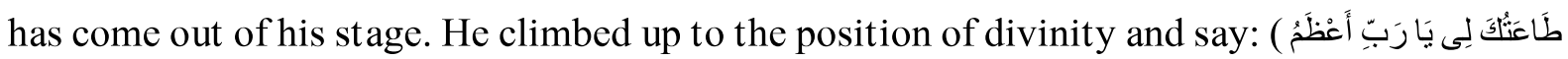

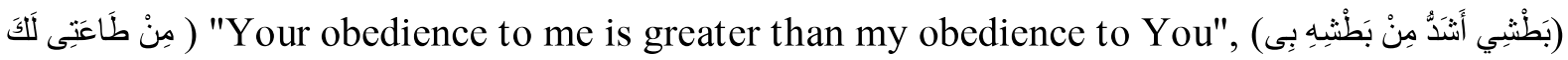

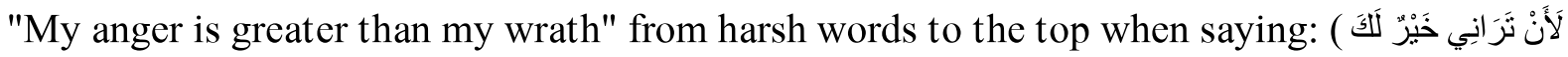
" that seeing me is better for you than seeing your god a thousand times". It is clear that he did not mean the primacy of the incarnation in this last sentence. With the meaning that he -who manifested real- is closer to the human soul than God because rationally God is far and difficult to understand. And seeing things that are close is better than seeing the distant ones which can be anchored like the incarnation of the Lord Jesus in Christianity.

Here, Abu Yazid did not mean that. In the condition of sakr he comes out of his stage and considers himself in the highest position of God himself. And this can be understood in terms of his personality because the opening of the hijab with high essence is a perfect essence with God. Because the influence in him becomes extreme at the farthest limits as one who witnesses every condition from this direction: one feels the highest reality a thousand times because of his abstraction caused by the strong gift of God that comes suddenly (Badawi, 1978: 37).

From this, it can be said that the last words of Abu Yazid were true in its disclosure when viewed from the psychological conditions that occurred at that time -in the sense that there were those who matched his actions from his emotions and reached the highest limits. There are no words from Sufi researchers except in terms of this psychology. Because of that this kind of sentence is not a little judged in showing Sufi personality from others which appear in the sense of lay humans that can be rationalized and accepted.

\section{b. Abu al-Husain al-Nūrỉ}

One of the expressions of ecstasy from him is saying:

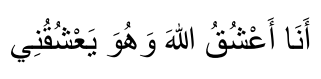

\section{"I miss God and He misses me"}

The expression occurs when it is heard by someone who does not like it and denies that statement and then takes it to the leader to be judged. Finally, Al-Nüri explained to the judge according to the word of Allah:

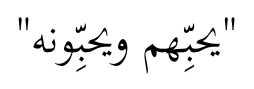

\section{"He loves them and they love Him" (QS. Al-Maidah: 54)}

Then Nuri continued his explanation to the judge, that longing ('Isyq) was not a higher position than love $(H u b b)$, as longing was forbidden while people who were in love were freed 
enjoying their love. Finally the judge accepted al-Nū ri's explanation well while crying (Sarraj, 1960: 407).

At another time it was also told that al-Nūri was once again reported to the judge, and they testified that al-Nū ri said:

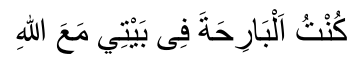

\section{"last night I was with God in my house",}

Then he was asked about the truth, then he answered that the utterance was really what he said, and said: "Even now I am with God, if I am at home then I am with Him, and if I am wherever I am with- Him, then whoever is with Allah in the world then in the Hereafter will be with Him" (Sarraj, 1960: 407), the meaning of the expression can be shown by the word of God QS. Qaf: 16:

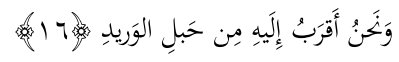

"We are closer to him than the veins of his neck".

From some of the stories of al-Nüri above, we sees that people who deny and blaspheme are from lay people who have little knowledge and do not want to ask people who understand it, because the meaning meant by al-Nüri clearly wants to show the verses of the Qur'an that are related to what is felt. Nuri was a Sufi teacher in his time, his worship was often referred to as a person who was persistent in fighting, as expressed by Abu Ahmad Al-Mughazali "I have never seen someone whose worship is better than Husayn al-Nüri", it was said he fasted for 20 years no one knew about it (Sarraj, 1960: 407).

In accordance with the ability of understanding the author, the words of al-Nüri show a strong Sufi love for the Creator (al-Khäliq). As if what he saw was Allah and what he remembered was only dhikr to Allah, Al-Qusyairi once said that actually love is a condition very noble because God will show his love for his believing servant (Al-Qusyairi, p. 318).

c. Manșūr al-Ḥallaj

Syaţahăt al-Hallāj which is the discussion in this study is Ana al-Haqq (أَنَا الْحَقُّ). In Akhbar al-Hallaj, Anjab al-Bagdadi narrated from Aḥmad bin Fātik said: I heard al-Hallaj said:

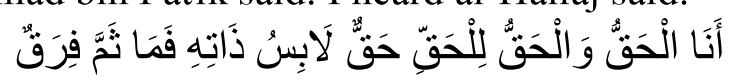

See also in Sarraj which takes from Tabaqāt al-Süfiyyah, al-Harawi, but in a different form, Syi'ir about al-Hallaj:

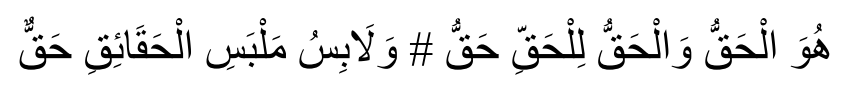

Teosofia: Indonesian Journal of Islamic Mysticism, Volume 7, Number 1, 2019 
In the book al-Amal al-Kamilah, (Abbas, 2004) shows the interpretation of al-Hallaj in Surat al-A'raf [7]: 205:

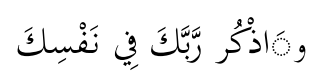

And call your Lord in your heart ...

In this verse you are not considered to show your remembrance to yourself, then you are required to have another remembrance instead. And the most noble remembrance is not to glorify anything except to the Haqq (Allah). And hidden in remembrance is more noble than visible remembrance (Abbas, 2004: 120).

And al-Hallaj's interpretation of the Letter of Jonah [10]: 32 is:

$$
\text { فَذَلِكُمُ اللَّهُ رَبُكُمُ الَْقُُّ }
$$

So (the Substance) That is the God of your true God.

Al-Haqq is the purpose of worship, and depends on it through obedience, does not appear besides Him, and is not found besides Him (Abbas, 2004: 122).

And al-Hallaj's interpretation of the Letter of Jonah [10]: 35:

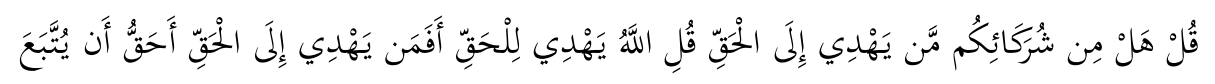

Say "Are there any of your allies who point to the truth?" Say "Allah is the one who points to the truth". So whether people who point to truth are more entitled to be followed.

Al-Husain was asked: Who is this Al-Haqq that you mean? He replied: He is the one who denounces humans and he is not reproachable Al-Haqq from Haqq, and for Haqq, He exists. Al-Haqq along with Haqq and none except seeing al-Haqq (Abbas, 2004: 122).

Here, the writer can capture that until the history mentioned by Anjab al-Bagdadi in Akhbar al-Hallaj, al-Bagdadi narrated from Ah mad bin Fā tik said: I heard al-Hallaj said: الْحَقُ (al-Bagdadi , 1997: 93) when al-Hallaj's heart was overpowered by the majesty of God (the appearance of ahwal) where it came suddenly, so al-Hallaj said "Ana al-Haqq" unconsciously.

Al-Hallaj did not care if he was sentenced to death, he was willing because it would bring him to meet al-Haqq. Therefore, it is undeniable that he could produce eccentric statements because of the strength of ecstasy, so at one time al-Hallaj said:

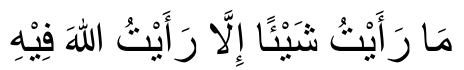

"I did not see anything except the God I saw in that thing."

And when there was someone asking him what was behind his robe, at that moment alHallaj unknowingly issued a word:

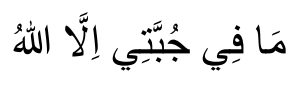




\section{"There is nothing in my robe except Allah."}

The release of the ecstatic expression when the Sufi condition of altered state of consciousness (ASC) occurs suddenly, he will not be able to avoid it because it comes from God. The release of the phrase ecstasy from someone is unexpected, a Sufi cannot predict when it will occur. The factor is when a Sufi is in danger because the source when it occurs is not from the tabi'at humans.

The author has hinted about the sakr until all conditions in the wajd are in full control syatahăt or prepare it to the point syatahăt. The perfect in the condition of the absence of the influence of rational thought which indicates consciousness. When sufistic conditions are not related to their essence to consciousness, even to fatigue and taste, then there will be a retreat of influence. When sufistic conditions are not related to their essence to consciousness, even to fatigue and taste, then there will be a retreat of influence. Because this justifies the initial position in soft conditions related to the birth of syatahat. And to the highest level, because the conditions are the main factor for each of these conditions; that is the condition that runs in the atmosphere from the absence of influence to the furthest possible limits for Sufis.

When the Sufi is aware of the state of ecstasy, it is enough for him, but if a Sufi is drunk ( sakr) then he will not be able to control his consciousness and will become a powerful factor syatahăt. In this state of drunkenness, Sufis are able to reach the level of wujüd which can deliver him to the peak experience.

\section{E. Conclusion}

From some of the research findings above, the authors conclude that the occurrence of the Sufis syatahăt begins when Allah tajalliy the Sufi heart where it comes suddenly, so that the Sufi cannot see anything except Allah, the tajalliy process tawäjud (prayer, dhikr, meditation, contemplation, tafakur) so that the Sufis reach the degree of wajd or ecstasy; and also as a result he was no longer able to control his consciousness and then issued syatahăt statement unintentional.

Syatahăt seen from the perspective of transpersonal psychology, grammatically, is an unusual combination of words to say by humans, because the context of the phrase is only for Allah. From the unusual utterances it is a manifestation of the psychological conditions of the Sufis themselves, where at the time of saying syatahat, the Sufis did not realize that they were saying these words.

\section{Bibliography}

Baharuddin, Paradigma Psikologi Islami; Studi Tentang Elemen Psikologi Dari Al- Qur'an, Jogjakarta: Pustaka Pelajar, 2004.

Ernst, Carl W, Ekspresi Ekstase dalam Sufisme, Yogyakarta: Putra Langit, 2003

Teosofia: Indonesian Journal of Islamic Mysticism, Volume 7, Number 1, 2019 
Al-Hujwiri, Ali ibn Usman, Kashf al-Mahjoob, translated by. JA. Nicolson, Lahore: Zia-ulQuran Publication, 2001.

Abbas, Qasim Muḥammad, Al-Ḥallaj: I'māl al-Kāmilah, Beirut: Riad al-Rayyes Books, 2002 , Abu Yazid al-Bustamī: al-Majmū'ah al-Ṣūfiyyah al-Kāmilah, Damascus: Al-Mada, 2004.

Al-Badawi, Abdurrahman, Syaṭaḥāt al-Ṣūfiyyah, Kuwait: Walakah al-Maṭbū'ah, 1960.

Al-Baghdadi, Ali ibn Anjab, Akhbar al-Ḥallaj min Andari al-Uṣul al-Makhtūtāt fí Sỉrati alHallaj, Damascus: Dār al-Thali'ah al-Jadidah, 1997.

Al-Ghazā̄i, Ihya' Ulūm al-Dīn, Kairo: Dar Ihya' al-Kutub al-Arabiyah, tt.

Al-Randi, Ibn 'Ibad Al-Nafazì, Syarḥ al-Ḥikam, Kairo: Dar Ihya' al-Kutub al-'Arabiyah, tt.

Al-Sulamī, Abu Abdirrahman, al-Ṭabaqāt al-Șūfiyyah, Beirut: Dār al-Kutub al-Hadisah, 2003.

Al-Tūsì, Sarraj, Al-Lumma' fi al-Tașawwuf, Mesir: Dar al-Kutub al-Hadisah, 1960. 